\title{
21. CRETACEOUS NANNOFOSSILS FROM THE NORTHWEST AFRICAN MARGIN, DEEP SEA DRILLING PROJECT LEG 791
}

\author{
George E. Wiegand, Department of Geology, Florida State University²
}

\begin{abstract}
Deep Sea Drilling Project Leg 79 recovered Cretaceous nannofossils at two localities, Sites 545 and 547 . Species diversity of the Cretaceous coccoliths is high, and the assemblages range in age from early Valanginian-early Hauterivian to latest Maestrichtian.

Site 545 and portions of Site 547 can be combined to form a composite section ranging from the upper Aptian-lower Albian to the middle to upper Cenomanian. As defined by nannofossil events, this section represents a complete record of sedimentary deposition. The interval appears to be the most extensive and complete Cretaceous section yet drilled off the Northwest African margin.

The Campanian and Maestrichtian sediments found at Site 547 (Hole 547A) are the youngest Cretaceous strata found on the Northwest African margin. Like the middle Cretaceous sections, the uppermost Maestrichtian of this interval also represents a complete record of sedimentation.
\end{abstract}

\section{INTRODUCTION}

During Deep Sea Drilling Project Leg 79, Sites 544, 545,546 , and 547 were drilled west of Morocco (Fig. 1). In situ Cretaceous sediments were recovered only from Sites 545 and 547 (Holes 547A and 547B). A primary goal of the cruise was to record the subsidence history of the carbonate platform seaward of the 3-km-high Mazagan Escarpment. It was hoped that calcareous nannofossils, foraminifers, and other fossil groups could be used to determine the age of sediments overlying the carbonate sequence and place age limits upon the drowning of the platform.

Situated on a slope at the base of the Mazagan Escarpment, Site 545 was positioned not only to investigate the subsidence of the platform but also to drill a Cretaceous sequence that recorded the erosional history of the steep escarpment.

Site 547 was located on the flank of a fault-controlled block, where it was believed that a thick Cretaceous sequence would be present. The sequence was drilled to recover a Cretaceous interval for biostratigraphic determinations and possibly to bracket more precisely unconformities dated in the Moroccan Basin on Leg 50. The recovery of Cretaceous sediments younger than Cenomanian was considered possible because of the thickness of the sequence. (No such sediments had previously been found on the Northwest African margin seaward of the continental shelf.)

Sediments from Sites 545 and 547 yielded Cretaceous nannofossils ranging in age from early Valanginian-early Hauterivian to late Maestrichtian. Table 1 lists the nannofossil taxa studied in this chapter. The majority of the bibliographic references for these taxa are given in Loeblich and Tappan (1966, 1968, 1969, 1970a, 1970b,

\footnotetext{
${ }^{1}$ Hinz, K., Winterer, E. L., et al., Init. Repts. DSDP, 79; Washington (U.S. Govt. Printing Office).

2 Address: Department of Geology, Florida State University, Tallahassee, Florida 32306.
}

1971, 1973) and in Heck (1979a, 1979b, 1980a, 1980b, 1981a, 1981b, 1982a, 1982b, 1983). References not found therein are listed in the references of this paper.

\section{METHODS AND PROCEDURES}

For this calcareous nannofossil study, standard smear slides of all samples were examined on the light microscope. The smear slides were prepared as uniformly as possible, to allow more accurate abundance estimates. If flocculation of sediments occurred, a small amount of $3-5 \%$ Calgon $\left[\left(\mathrm{NaPO}_{3}\right)_{6}\right]$ solution was added to the slide to aid in dispersion.

Each smear slide was studied on the light microscope by making approximately 10 traverses across the slide at $1562 \times$ magnification. For each of the samples analyzed two abundances are given: the abundance of calcareous nannofossils on the slide and the abundance of individual species, as follows

\begin{tabular}{|c|c|}
\hline $\begin{array}{l}\text { Nannofossil specimens } \\
\text { per field of view }\end{array}$ & $\begin{array}{c}\text { Individual } \\
\text { species abundance } \\
\text { per field of view }\end{array}$ \\
\hline $\begin{array}{l}\mathrm{A}=\text { abundant } ; 70+ \\
\mathrm{V}=\text { very common; } 50-69 \\
\mathrm{C}=\text { common; } 30-49 \\
\mathrm{~F}=\text { few; } 10-29 \\
\mathrm{R}=\text { rare; } 1-9 \\
\mathrm{E}=\text { essentially barren; } 1 \\
\quad \text { specimen every } 2 \text { or } \\
\text { more fields, } \\
\mathrm{B}=\text { barren; no nanno- } \\
\text { fossils observed }\end{array}$ & $\begin{array}{l}\mathrm{D}=\text { very abundant; } 10 \text { or } \\
\text { more specimens } \\
\mathrm{A}=\text { abundant; } 6 \text { to } 9 \\
\text { specimens } \\
\mathrm{V}=\text { very common; } 3 \text { to } 5 \\
\text { specimens } \\
\mathrm{C}=\text { common; } 1 \text { to } 2 \\
\text { specimens } \\
\mathrm{M}=\text { moderately common; } \\
\begin{array}{l}1 \text { specimen every } 2-40 \\
\text { fields }\end{array} \\
\mathrm{F}=\text { few; } 1 \text { specimen every } \\
\quad 41-60 \text { fields } \\
\mathrm{R}=\text { rare; } 1 \text { specimen eve- } \\
\text { ry } 61-120 \text { fields } \\
\mathrm{P}=\text { present; } 1 \text { specimen } \\
\text { every } 121 \text { or more } \\
\text { fields }\end{array}$ \\
\hline
\end{tabular}

In Tables 2 and 3 abundances of reworked nannofossils are listed in lower-case letters; in situ taxa are in capital letters.

Preservation of the calcareous nannofossils in each sample was recorded as follows:

$\mathrm{G}=$ Good; specimens show little or no dissolution and/or overgrowth; 


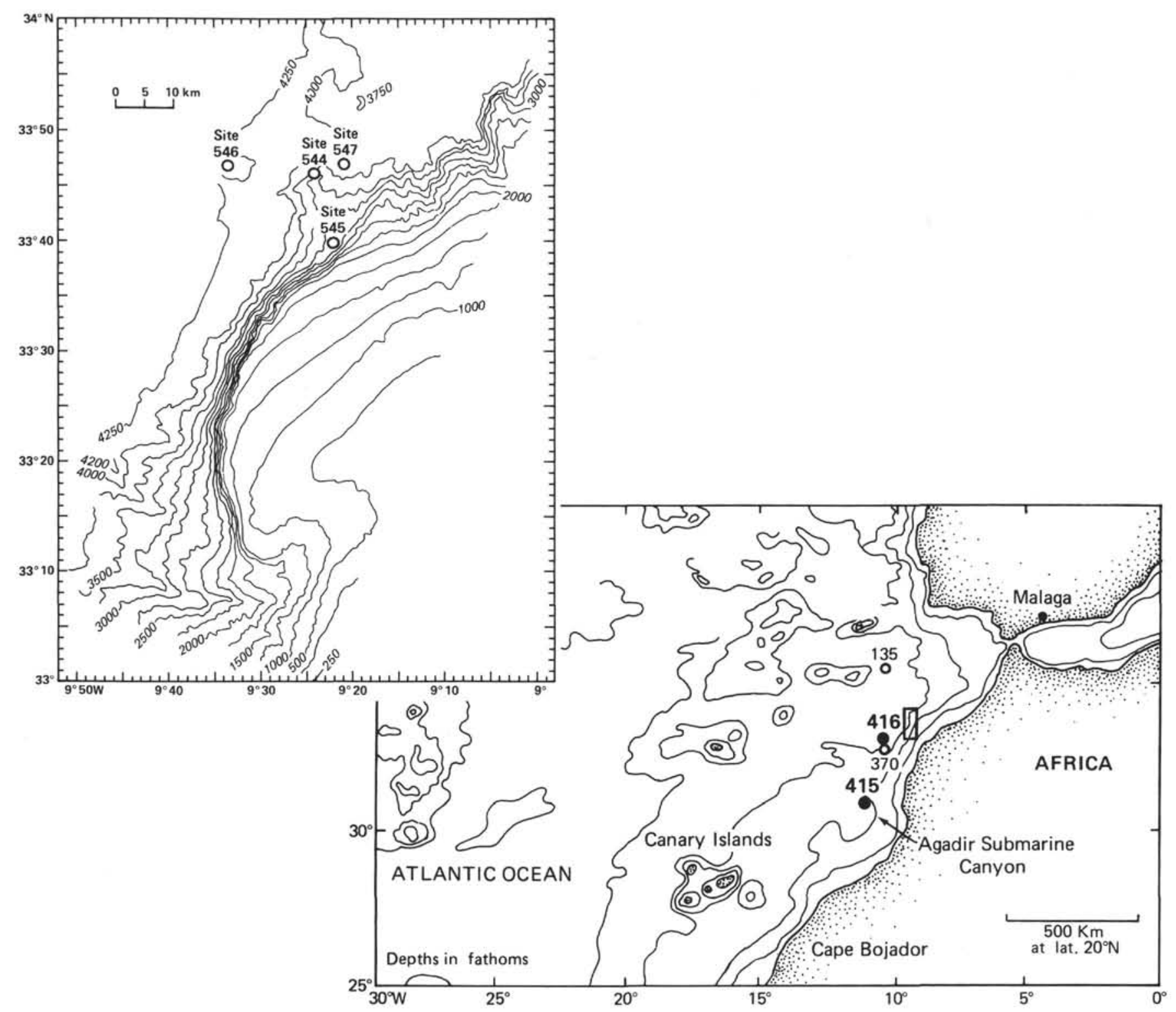

Figure 1. Location of sites drilled on Leg 79 and other DSDP legs recovering Cretaceous sediments off the Northwest African margin.

M = Moderate; specimens show some dissolution and/or overgrowth, but identification of taxa is possible;

$\mathrm{P}=$ Poor; specimens show extreme dissolution and/or overgrowth; identification of taxa usually possible but sometimes impaired.

\section{CALCAREOUS NANNOFOSSIL BIOSTRATIGRAPHY AND ZONATION}

The Cretaceous nannofossils of Leg 79 could not be zoned according to a single published zonation: some zones were difficult to determine and biostratigraphic resolution was lacking within others. Thus, a combination of three published zonations is used here: Thierstein (1973), from the earliest Berriasian to the late Albian; Manivit et al., (1977), from the late Albian to the late Turonian; and Verbeek (1977), from the late Turonian to the end of the Maestrichtian. The combined zonal scheme is illustrated in Figure 2. Even with this combination of zonations, other datum levels, including some of Perch-Nielsen (1979), were incorporated within zones to increase resolution or to improve zonal utility. This chapter uses a different zonal approach than that used in the site chapters for Leg 79.

The Nannoconus colomii Zone and the Cretarhabdus crenulatus Zone of Thierstein (1973) are not recognized in the samples studied. These zones range in age from the earliest Berriasian to the early Valanginian.

\section{Calcicalathina oblongata Zone}

Author. Thierstein (1971), modified by Thierstein (1973).

Definition. Interval from the first occurrence of $C$. oblongata to the first occurrence of Lithraphidites bollii.

Age. Early Valanginian-early Hauterivian.

Remarks. This zone is recognized in only two samples, 547B-6-1, 139-140 cm and 547B-6-2, 6-7 cm. The first sample contains Diadorhombus rectus which, according to Thierstein (1976), ranges within the mid-Valanginian. Wind and Čepek (1979) questioned this limited 
Table 1. Nannofossil species considered in this study, listed alphabetically by specific name.

Corollithion achylosum (Stover) Thierstein, 1971

Ceratolithoides aculeus (Stradner) Prins and Sissingh in Sissingh, 1977

Lithraphidites acutum ssp. eccentricum Watkins (in press)

Braarudosphaera africana Stradner, 1961

Lithraphidites alatus Thierstein, 1972

Axopodorhabdus albianus (Black) Wind and Wise, 1976

Hayesites albiensis Manivit, 1971

Crucicribrum anglicum Black, 1973

Vekshinella angusta (Stover) Verbeek, 1977

Rhagodiscus angustus (Stradner) Reinhardt, 1971

Reinhardtites anthophorus (Deflandre) Perch-Nielsen, 1968

Rhagodiscus asper (Stradner) Reinhardt, 1967

Markalius astroporus (Stradner) Hay and Mohler, 1967

Watznaueria barnesae (Black) Perch-Nielsen, 1968

Microrhabdulus belgicus Hay and Towe, 1963

Cylindralithus biarcus Bukry, 1969

Flabellites biforaminis Thierstein, 1973

Watznaueria biporta Bukry, 1969

Discorhabdus biradiatus (Worsley) Thierstein, 1973

Watznaueria britannica (Stradner) Reinhardt, 1964

Amphizygus brooksii Bukry, 1969

Lithraphidites carniolensis Deflandre, 1963

Cruciellipsis chiastia (Worsley) Thierstein, 1972

Speetonia colligata Black, 1971

Nannoconus colomii (deLapparent) Kamptner, 1938

Micula concava (Stradner) Bukry, 1969

Cretarhabdus conicus Bramlette and Martini, 1964

Grantarhabdus coronadventis (Reinhardt) Grün, 1975

Cretarhabdus crenulatus Bramlette and Martini, 1964

Prediscosphaera cretacea (Arkhangelsky) Gartner, 1968

Cruciellipsis cuvillieri (Manivit) Thierstein, 197।

Arkangelskiella cymbiformis Vekshina, 1959

Microrhabdulus decoratus Deflandre, 1959

Tetrapodorhabdus decorus (Deflandre) Wind and Wise, 1977

Micula decussata Vekshina, 1959

Axopodorhabdus dietzmanni (Reinhardt) Wind and Wise, 1977

Zygodiscus diplogrammus (Deflandre) Gartner, 1968

Cribrosphaerella ehrenbergii (Arkhangelsky) Deflandre, 1952

Biscutum ellipticum (Gorka) Grün and Allemann, 1975

Nannoconus elongatus Bronnimann, 1955

Parhabdolithus embergeri (Noël) Stradner, 1965

Zeugrhabdotus erectus (Deflandre) Stradner, 1965

Eiffellithus eximius (Stover) Perch-Nielsen, 1968

Eprolithus floralis (Stradner) Stover, 1966

Scapholithus fossilis Deflandre, 1954

Marthasterites furcatus (Deflandre) Deflandre, 1959

Tranolithus gabalus Stover, 1966

Chiastozygus garrisonii Bukry, 1969

Quadrum gartneri Prins and Perch-Nielsen in Manivit et al., 1977

Corollithion geometricum (Gorka) Manivit, 1971

Quadrum gothicum (Deflandre) Prins and Perch-Nielsen in Manivit et al. 1977

Lithastrinus grillii Stradner, 1962

Lithraphidites helicoideus (Deflandre) Deflandre, 1963

Braarudosphaera hockwoldensis Black, 1973

Sollasites horticus (Stradner, Adamiker, and Maresch) Black, 1968

Micrantholithus hoschulzi (Reinhardt) Thierstein, 1971

Bidiscus ignotus (Gorka) Lauer in Grün et al., 1972

Parhabdolithus infinitus (Worsley) Thierstein, 1974

Markalius inversus (Deflandre) Bramlette and Martini, 1964

Rucinolithus irregularis Thierstein, 1972

Ceratolithoides kamptneri (Bramlette and Martini) Verbeek, 1976b

Broinsonia lacunosa Forchheimer, 1972

Stephanolithion laffittei Noël, 1957

Diazmatolithus lehmani Noël, 1965

Chiastozygus litterarius (Gorka) Manivit, 1971

Cretarhabdus loriei Gartner, 1968

Kamptnerius magnificus Deflandre, 1959

Cyclagelosphaera margereli Noël, 1965

Vagalapilla matalosa (Stover) Thierstein, 1973

Conusphaera mexicana Trejo, 1969

Braarudosphaera minute Filewicz, Wind, and Wise in Wind and Wise, 1976 Micula mura (Martini) Bukry, 1963

Quadrum nitidum (Martini) Prins and Perch-Nielsen in Manivit et al., 1977

Gartnerago obliquum (Stradner) Noël, 1970

Calcicalathina oblongata (Worsley) Thierstein, 1971

Micrantholithus obtusus Stradner, 1963

Ahmuellerella octoradiata (Gorka) Reinhardt, 1970

Thanolithus orionatus Stover, 1966

Broinsonia parca (Stradner) Bukry, 1969
Table 1. (Continued).

Manivitella pemmatoidea (Deflandre ex Manivit) Thierstein, 1971

Lithraphidites praequadratus Roth, 1978

Micula prinsii Perch-Nielsen, 1979

Corollithion protosignum Worsley, 1971

Lithraphidites quadratus Bramlette and Martini, 1964

Nannoconus quadriangulus Deflandre and Deflandre-Rigaud, 1962

Nannoconus quadriangulus apertus Deflandre and Deflandre-Rigaud, 1962

Diadorhombus rectus Worsley, 1971

Ahmuellerella regularis (Gorka) Verbeek, 1977

Braarudosphaera regularis Black, 1973

Octocyclus reinhardtii (Bukry) Wind and Wise, 1977

Corollithion rhombicus (Stradner and Adamiker) Bukry, 1969

Retecapsa schizobrachiata (Gartner) Grün, 1975

Cylindralithus serratus Bramlette and Martini, 1964

Broinsonia signata (Noël) Noël, 1970

Corollithion signum Stradner, 1963

Arkhangelskiella specillata Vekshina, 1959

Zygodiscus spiralis Bramlette and Martini, 1964

Rhagodiscus splendens (Deflandre) Verbeek, 1977

Braarudosphaera stenorheta Hill, 1976

Vagalapilla stradneri (Rood et al.) Thierstein, 1973

Gartnerago striatum (Stradner) Forchheimer, 1972

Cretarhabdus surirellus (Deflandre and Fert) Reinhardt emend. Thierstein, 1971

Eiffellithus trabeculatus (Gorka) Reinhardt and Gorka, 1967

Quadrum trifidum (Stradner) Prins and Perch-Nielsen in Manivit et al., 1977

Nannoconus truitti Bronnimann, 1955

Eiffellithus turriseiffeli (Deflandre) Reinhardt, 1965

Biscutum sp.

Chiastozygus sp.

Corollithion sp.

Lithistrinus sp.

Lucianorhabdus sp.

Seribiscutum sp.

Stradnerlithus sp.

Tetralithus sp.

Zygodiscus sp. 1

Zygodiscus sp. 2

Zygodiscus sp. 3

Zygodiscus sp. 4 (small)

Genus et sp. indet. 1

range, suggesting that $D$. rectus may extend into the Hauterivian. With only one sample containing $D$. rectus, this study can add no new information on its range.

The following zones, from Thierstein (1973), are not recognized in the samples studied: Lithraphidites bollii Zone, Micrantholithus hoschulzi Zone, and Chiastozygus litterarius Zone. These range in age from the early Hauterivian to the early Aptian.

\section{Rhagodiscus angustus Zone}

Author. Manivit (1971), modified by Thierstein (1973).

Definition. Interval from the first occurrence of $R$. angustus and/or Eprolithus floralis to the first occurrence of Prediscosphaera cretacea.

Age. Late Aptian-early Albian.

Remarks. The first occurrence of $R$. angustus, in this study, is not coincident with the first appearance of $E$. floralis as reported by Manivit (1971) and Thierstein (1973), but is encountered in younger sediments (Table 2, later). Perch-Nielsen (1979) also reports that $R$. angustus was found in sediments younger than $E$. floralis. Thus, in this study, the lowest occurrence of $E$. floralis is used as the lower boundary of the zone.

$R$. angustus was found somewhat inconsistently throughout the intervals studied, especially in Holes 547A 


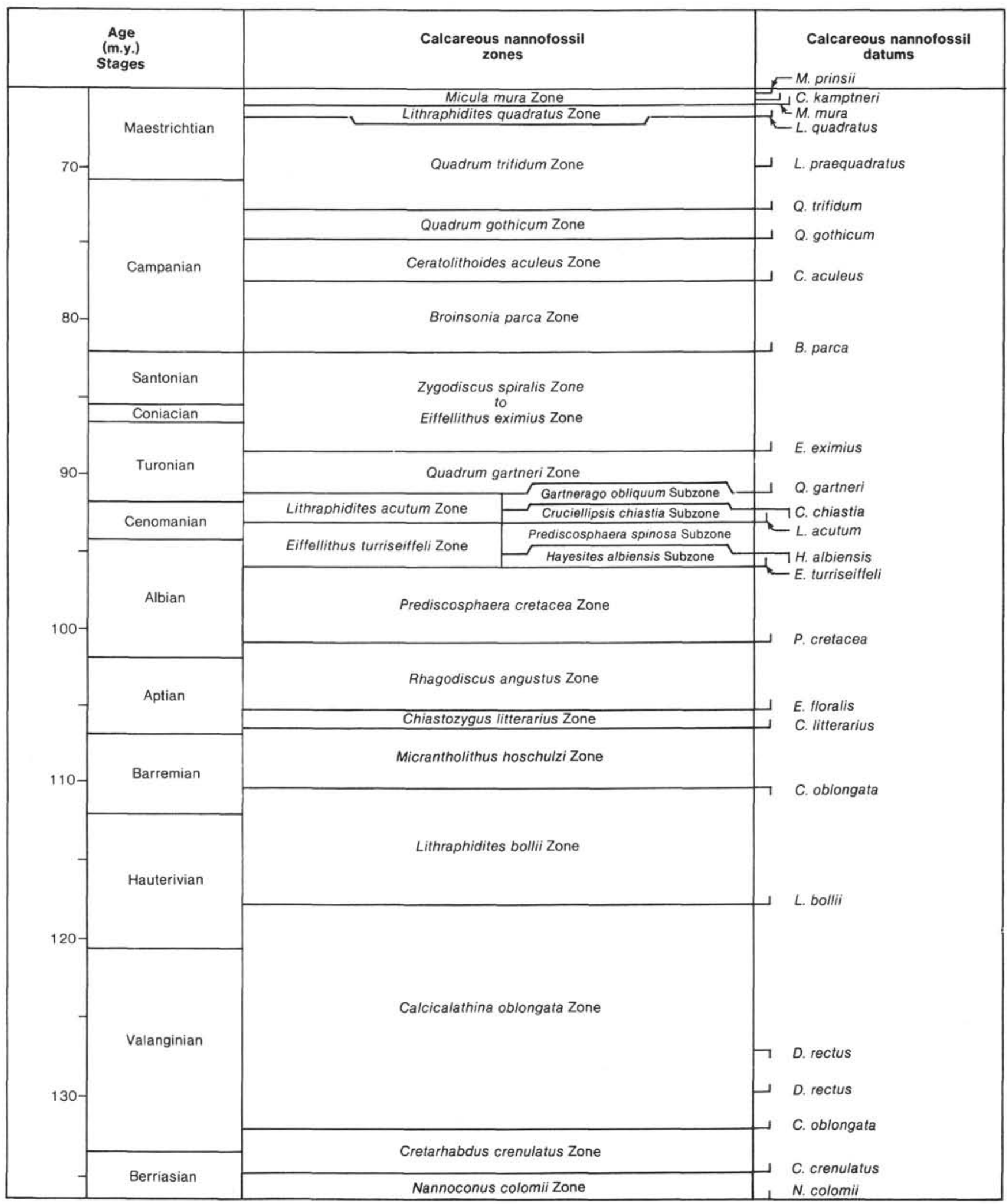

Figure 2. Cretaceous nannofossil zonal scheme used in this chapter. Sources: Thierstein (1973), Manivit et al., (1977), and Verbeek (1977). 
and 547B. Preservation did not seem to be a factor: in many samples where $R$. angustus was absent preservation was good. Varying environmental conditions may be responsible for the sporadic occurrences of this coccolith.

The zone is recognized in Samples 545-56-6, 64-65 cm to $545-47-4,47-48 \mathrm{~cm}$; it is not present in Holes $547 \mathrm{~A}$ or $547 \mathrm{~B}$.

\section{Prediscosphaera cretacea Zone}

Author. Thierstein (1971), modified by Thierstein (1973).

Definition. Interval from the first occurrence of $P$. cretacea to the first occurrence of Eiffellithus turriseiffeli.

Age. Early Albian-middle Albian.

Remarks. Manivit et al. (1977), unlike Thierstein (1973), distinguish $P$. cretacea from the smaller $P$. columnata and place the first occurrence of $P$. columnata at the level of the first appearance of $P$. cretacea according to Thierstein, 1973. Thus the $P$. cretacea Zone of Thierstein (1973) is equivalent to the $P$. columnata Zone of Manivit et al. (1977); both zones have the first occurrence of Eiffellithus turriseiffeli as the upper boundary datum. Following Thierstein, $P$. columnata is not separated from $P$. cretacea in this study.

This zone is recognized in the interval from Samples $545-47-3,30-31 \mathrm{~cm}$ to $545-41-1,42-43 \mathrm{~cm}$. It is not present in Holes 547A or 547B.

\section{Eiffellithus turriseiffeli Zone}

Author. Thierstein (1971), modified by Manivit et al. (1977).

Definition. Interval from the first occurrence of $E$. turriseiffeli to the first occurrence of Lithraphidites acutum.

Age. Late Albian-middle Cenomanian.

Remarks. Manivit et al. (1977) recognize two subzones within this zone: Hayesites albiensis and Prediscosphaera spinosa subzones.

\section{Hayesites albiensis Subzone}

Authors. Manivit et al. (1977).

Definition. Interval from the first occurrence of Eiffellithus turriseiffeli to the last occurrence of $H$. albiensis.

Age. Late Albian.

Remarks. This subzone is present from Samples $545-40-6,78 \mathrm{~cm}$ to $545-38-3,92-93 \mathrm{~cm}$, and $547 \mathrm{~B}-6-1$, $39-41 \mathrm{~cm}$ to $547 \mathrm{~A}-63-1,77-78 \mathrm{~cm}$.

\section{Prediscosphaera spinosa Subzone}

Authors. Manivit et al. (1977).

Definition. Interval from the last occurrence of Hayesites albiensis to the first occurrence of Lithraphidites acutum.

Age. Latest Albian-middle Cenomanian.

Remarks. This subzone is recognized from Samples 545-38-1, 92-93 cm to 545-30-1, 27-28 cm, and Samples $547-62-2,77-78 \mathrm{~cm}$ to $547 \mathrm{~A}-46-3,32-33 \mathrm{~cm}$.

\section{Lithraphidites acutum Zone}

Author. Verbeek, in Manivit et al. (1977).

Definition. Interval from the first occurrence of $L$. acutum to the first occurrence of Quadrum gartneri.

Age. Middle Cenomanian-early Turonian.

Remarks. This zone is divided into two subzones by Manivit et al.: Cruciellipsis chiastia and Gartnerago obliquum subzones. Only the first of these is recognized here.

\section{Cruciellipsis chiastia Subzone}

Authors. Manivit et al. (1977).

Definition. Interval from the first occurrence of Lithraphidites acutum to the last occurrence of $C$. chiastia.

Age. Middle Cenomanian-late Cenomanian.

Remarks. This subzone is recognized from Samples 545-29-2, 68-69 $\mathrm{cm}$ to $545-28-1,9-10 \mathrm{~cm}$, and Samples $547 \mathrm{~A}-46-2,32-33 \mathrm{~cm}$ to $547 \mathrm{~A}-39-1,10-11 \mathrm{~cm}$.

The Quadrum gartneri Zone from Manivit et al. (1977) is not present in the samples studied. This zone and the preceding $G$. obliquum subzone range from the late $\mathrm{Ce}-$ nomanian to the late Turonian in age.

The following zones, from Verbeek (1977), were not present in the study material: Eiffellithus eximius Zone; Marthasterites furcatus Zone; Broinsonia lacunosa Zone; Micula concava Zone; Rucinolithus hayi Zone; Zygodiscus spiralis Zone; and Broinsonia parca Zone. These zones range from late Turonian to early Campanian in age.

\section{Ceratolithoides aculeus Zone}

Author. Verbeek (1977).

Definition. Interval from the first occurrence of $C$. aculeus to the first occurrence of Quadrum gothicum.

Age. Early Campanian-middle Campanian.

Remarks. This zone is found from Samples 547A-38-3, $12-13 \mathrm{~cm}$ to $547 \mathrm{~A}-38-1,134-135 \mathrm{~cm}$; it is not present at Site 545 .

\section{Quadrum gothicum Zone}

Author. Martini (1976), in Verbeek (1977).

Definition. Interval from the first occurrence of $Q$. gothicum to the first occurrence of $Q$. trifidum.

Age. Middle Campanian.

Remarks. This zone is recognized only from Samples $547 \mathrm{~A}-37-4,65-66 \mathrm{~cm}$ to $547 \mathrm{~A}-36-2,82-83 \mathrm{~cm}$.

\section{Quadrum trifidum Zone}

Author. Verbeek (1977).

Definition. Interval from the first occurrence of $Q$. trifidum to the first occurrence of Lithraphidites quadratus.

Age. Late Campanian-middle Maestrichtian.

Remarks. As defined by Verbeek (1977), the original upper limit of this zone was the early Maestrichtian, based on the first occurrence of L. quadratus. However, many authors, including Thierstein (1976), Sissingh (1977), 
Roth (1978), and Perch-Nielsen (1979), place the first appearance of $L$. quadratus in the middle Maestrichtian. In this study, the first occurrence of $L$. quadratus is elevated to the middle Maestrichtian level at which Sissingh (1977) and Perch-Nielsen (1979) place it, and a first occurrence datum for $L$. praequadratus is then erected at the level of Verbeek's L. quadratus datum (early Maestrichtian). This leaves the Quadrum trifidum Zone with its original boundary datums but raises the upper boundary to the middle rather than lower Maestrichtian, thus extending the range of the zone. The $L$. quadratus Zone thus also retains its original boundary datums but is given a shorter range.

Samples 547A-36-1, 26-27 cm to 547A-35-1, 67-68 cm are assigned to the interval from the base of this zone to the L. praequadratus datum. No nannofossils were found in this zone above the $L$. praequadratus datum.

\section{Lithraphidites quadratus Zone}

Authors. Bukry and Bramlette (1970), in Verbeek (1977).

Definition. Interval from the first occurrence of $L$. quadratus to the first occurrence of Micula mura.

Age. Middle Maestrichtian.

Remarks. This zone is present only in Samples $547 \mathrm{~A}-34-7,14-15 \mathrm{~cm}$ to $547 \mathrm{~A}-33-5,49-50 \mathrm{~cm}$.

\section{Micula mura Zone}

Authors. Bukry and Bramlette (1970), in Verbeek (1977).

Definition. Interval from the first occurrence of $M$. mura to the extinction of most Cretaceous calcareous nannofossils.

Age. Late Maestrichtian.

Remarks. To further divide the latest Maestrichtian, two datum levels of Perch-Nielsen (1979) are used within this zone. The datum levels are defined by the first occurrences of Ceratolithoides kamptneri and Micula prinsii.

Samples 547 A-33-4, 119-120 cm to 547A-33-1, 86-87 $\mathrm{cm}$ are within the interval bounded by the base of the zone and the $C$. kamptneri first occurrence datum. The interval between the first occurrence of $C$. kamptneri and the first occurrence of $M$. prinsii is recognized in Samples 547A-33-1, 86-87 cm to 547A-33-1, $16 \mathrm{~cm}$. Samples $547 \mathrm{~A}-32, \mathrm{CC}(16 \mathrm{~cm})$ to $547 \mathrm{~A}-32-4,67 \mathrm{~cm}$ fall within the interval bounded by the first occurrence of $M$. prinsii and the extinction of most Cretaceous nannofossils. This zone is not recognized at Site 545 .

Site 545 ( $33^{\circ} 39.86^{\prime} \mathbf{N}$; $09^{\circ} 21.88^{\prime}$ W; water depth $3142 \mathrm{~m}$ )

Site 545 was drilled northwest of the Mazagan Plateau, at the base of the Mazagan Escarpment. The Cretaceous sediments recovered are $276 \mathrm{~m}$ thick and consist predominantly of a greenish gray nannofossil claystone. Nannofossil diversity at this site is generally high. A range chart showing species abundance and distribution is given in Table 2 .

The middle to upper Cenomanian (Lithraphidites acutum Zone, Cruciellipsis chiastia Subzone) is present from Samples 545-28-1, 9-10 cm to 545-29-2, 68-69 cm (255-
$274 \mathrm{~m}$ ). The nannofossil abundances range from common to very common and preservation is good.

Mid-Cenomanian to upper Albian sediments (Eiffellithus turriseiffeli Zone) are present from Samples $545-30-1,27-28 \mathrm{~cm}$ to $545-40-6,7-8 \mathrm{~cm}(274-379 \mathrm{~m})$. The coccolith assemblages are very common to abundant and are well preserved.

The upper Albian to upper Aptian (Prediscosphaera cretacea Zone and Rhagodiscus angustus Zone) is recognized in Samples 545-41-1, 42-43 cm to 545-56-6, $64-65 \mathrm{~cm}(379-531 \mathrm{~m})$. Preservation of the nannoflora is generally good with the abundances ranging from common to abundant. The lithology of Samples 545-56-1, $0 \mathrm{~cm}$ through $545-56-4,40 \mathrm{~cm}$ is a muddy nannofossil ooze; this is different from the nannofossil claystone of the overlying Cretaceous sediments. Below this, in the lowest few meters of the core, a dolomitized clayey nannofossil chalk is found. Corresponding to this increase in dolomitization is a rapid decrease in the abundance and preservation of the nannofossil assemblages. Sample $545-56-6,64-65 \mathrm{~cm}$ has a moderate preservation, rare specimens, and abundant dolomite rhombs. Core 57 is dolomitized limestone thought to be Middle-Late Jurassic in age.

\section{Site $547\left(3^{\circ} 46.84^{\prime} \mathrm{N} ; 0^{\circ} 20.98^{\prime} \mathrm{W}\right.$; water depth $\left.3939 \mathrm{~m}\right)$}

Site 547 was drilled on the northeastern flank of the same fault-controlled sialic block as Site 544. A total of $404 \mathrm{~m}$ of Cretaceous sediments were drilled at Site 547, which includes Hole 547A and Hole 547B (a reentry hole). The calcareous nannofloral diversity is typically high at this site. A range chart showing species abundance and distribution is given in Table 3 .

The Maestrichtian and Campanian sediments, are composed primarily of greenish gray nannofossil chalk. The upper Maestrichtian (Micula mura Zone) is recognized in Samples 547A-32-4, $67 \mathrm{~cm}$ to $547 \mathrm{~A}-33-4,119-120 \mathrm{~cm}$ $(\sim 370-\sim 379.5 \mathrm{~m})$. This zone is further subdivided by the $C$. kamptneri and $M$. prinsii first occurrence datums, showing the continuity of the latest Maestrichtian at this site. The nannofossil assemblage has moderate to good preservation, and abundances vary from few to abundant.

Middle Maestrichtian sediments (Lithraphidites quadratus Zone) are found in Samples 547A-33-5, 49-50 cm to $547 \mathrm{~A}-34-7,14-15 \mathrm{~cm}(\sim 379.5-393 \mathrm{~m})$. Preservation is moderate to good and the abundance is generally common to very common. Reworking of older nannofossils is evident within some samples of this zone. The reworked taxa include Broinsonia parca, Quadrum gothicum, $Q$. trifidum, Q. nitidum, Eiffellithus eximius; Marthasterites furcatus; and Lithastrinus grilli. The nannofossils $B$. parca, $Q$. gothicum, $Q$. trifidum, L. grilli, and E. eximius are found in situ beneath an unconformity between Cores 34 and 35 (Table 3). M. furcatus and $Q$. nitidum are not found in any sediments beneath the reworked interval, including those just above the extensive hiatus (between Cores 38 and 39) which marks the absence of the upper Cenomanian to lower Campanian. It could be expected that a taxon ranging only during the time of a hiatus might be found immediately above that 
hiatus, but it is not likely that it would be found above a younger hiatus, as is the case here with $M$. furcatus. Neither $M$. furcatus nor $Q$. nitidum are found in sediments beneath the reworked interval, and it would appear that they were transported from outside the study area, possibly upslope from the site location. The other five reworked taxa may have come from the sediments beneath the hiatus or from outside the study area. Regardless of where these reworked taxa originated, it is clear that at least two horizons of coccoliths were eroded to provide the reworked nannofossil assemblage, because the stratigraphic range of $M$. furcatus (Coniacian to lower Campanian) does not overlap those of $Q$. gothicum (mid-Campanian to lower Maestrichtian) or $Q$. trifidum (upper Campanian to lower Maestrichtian). Toward the hiatus between Cores 34 and 35, reworked nannofossils become more common. This unconformity separates the Lithraphidites quadratus Zone (mid-Maestrichtian) from the older $Q$. trifidum Zone (late Campanian-early Maestrichtian). Samples 547A-35-1, 67-68 $\mathrm{cm}$ to $547 \mathrm{~A}-36-1,26-27 \mathrm{~cm}(393-\sim 398 \mathrm{~m})$ belong to the $Q$. trifidum Zone. Preservation is moderate to good, with abundances tabulated as very common.

The middle to lower Campanian $(Q$. gothicum and Ceratolithoides aculeus zones) is present in Samples $547 \mathrm{~A}-36-2,82-83 \mathrm{~cm}$ to $547 \mathrm{~A}-38-3,12-13 \mathrm{~cm}$ ( $2398-$ $421.5 \mathrm{~m}$ ). The coccoliths in this interval differ from the overlying Upper Cretaceous assemblages; preservation is generally poor to moderate and nannofossils are few to very common in abundance.

Coinciding with the hiatus between Cores 38 (C. aculeus Zone) and 39 (L. acutum Zone) is a lithology change from the overlying nannofossil chalk to nannofossil-bearing claystone beneath. Because of bioturbation, evidenced by burrows, younger coccoliths from the interval above the hiatus have been transported downward into Sample $547 \mathrm{~A}-39-1,10-11 \mathrm{~cm}$. The transported nannofossil assemblage is reduced in both abundance and diversity from the in situ assemblage above.

Samples $547 \mathrm{~A}-39-1,10-11 \mathrm{~cm}$ to $547 \mathrm{~A}-46-2,32-33 \mathrm{~cm}$ $(421.5-\sim 490 \mathrm{~m})$ are assigned to the L. acutum Zone, Cruciellipsis chiastia Subzone of middle-late Cenomanian age. Preservation of the nannofossil assemblage is good, and specimens are very common to abundant. The main lithology of this interval is a grayish green nannofossil-bearing claystone, much like that of the Cenomanian to Aptian of Site 545 .

The middle Cenomanian to the uppermost Albian (Eiffellithus turriseiffeli Zone) is represented in Samples $547 \mathrm{~A}-46-3,32-33 \mathrm{~cm}$ to $547 \mathrm{~B}-6-1,39-41 \mathrm{~cm}$ ( 490$\sim 772.5 \mathrm{~cm}$ ). The mid-Cenomanian to uppermost Albian sediments (Cores 39 to 62) are generally composed of grayish green nannofossil-bearing claystone similar to that found above. The remainder of the upper Albian (Cores 547A-63 to 547B-6-1, $105 \mathrm{~cm}$ ) consist predominantly of interbedded nannofossil mudstone and nannofossil-bearing claystone. It has been determined that little overlap occurs between Hole 547A and the reentry hole Hole 547B; Core 73 of Hole 547A correlates with Core 1 of Hole 547B (see Site 547 site chapter, this volume).
An apparent unconformity exists between Samples 547B-6-1, 39-41 cm (E. turriseiffeli Zone) and 547B-6-1, 139-140 cm (Calcicalathina oblongata Zone). The abundance of the nannofossil assemblage in Sample 547B-6-1, $139-140 \mathrm{~cm}(\sim 773.4 \mathrm{~m})$ is common, and preservation is moderate. Sample 547B-6-2, 6-7 cm $(\sim 773.6 \mathrm{~m})$ has good preservation and very common specimens. Both samples are early Valanginian-early Hauterivian in age and correspond to the Calcicalathina oblongata Zone. Samples 547B-6-1, 139-140 cm, 547B-6-2, 6-7 cm, and 547B-6-3, 57-58 cm were taken from claystones interbedded with bioclastic wackestones and limestone conglomerates.

The age of Sample 547B-6-3, 57-58 cm ( 775.6 m) is indeterminate because preservation was poor and specimens are few.

\section{Hiatuses}

As indicated above, a number of significant hiatuses are present in these sections. The Cenomanian of Site 545 lies unconformably beneath lower-middle Miocene sediments. Another unconformity exists between the upper Aptian-lower Albian dolomitized sediments and the Middle-Upper Jurassic dolomite (see Site 545 site chapter, this volume). No other hiatuses are evident within the Cretaceous of this site.

The uppermost Maestrichtian of Hole 547A lies beneath sediments of early Danian age. However, the sequence spanning the Cretaceous/Tertiary boundary is not continuous, since the Biantholithus sparsus Zone (Romein, 1977), earliest Danian, is apparently absent. A more detailed study of the Cretaceous/Tertiary boundary drilled during this cruise is planned.

A hiatus in Hole 547A, between Samples 547A-34-7, 14-15 cm (middle Maestrichtian) and 547A-35-1, 67-68 $\mathrm{cm}$ (late Campanian-early Maestrichtian) spans a time of between 4 and $7 \mathrm{~m}$.y. approximately, according to the absolute time scale (Fig. 2) utilized by Thierstein (1976).

The major hiatus, noted between Samples 547A-38-3, 12-13 cm (early-middle Campanian) and 547A-39-1, $10-11 \mathrm{~cm}$ (middle-late Cenomanian) represents 14 to 19 m.y., approximately and excludes the lowermost Campanian, Santonian, Coniacian, Turonian, and uppermost Cenomanian from the sedimentary record.

A disconformity lies between Samples 547B-6-1, 39$41 \mathrm{~cm}$ (upper Albian) and 547B-6-1, 139-140 cm (lower Valanginian-lower Hauterivian). The short interval $(1 \mathrm{~m})$ between the two samples represents some 22 to $37 \mathrm{~m}$.y., suggesting the existence of one or more hiatuses. The presence of limestone beds between the samples makes it difficult to pinpoint precisely the position of the disconformity using nannofossil biostratigraphy, because the interval could not be studied by smear slides. Lower in the section, Sample 547B-6-2, 6-7 cm, of early Valanginian-early Hauterivian age, and Sample 547B-6-4, $47-48 \mathrm{~cm}$, of Late Jurassic age, are also separated by a limestone sequence; thus it is again difficult to establish the position of a probable hiatus. This is especially true since the age of Sample 547B-6-3, 57-58 cm is undetermined. 
Table 2. Distribution of Cretaceous nannofossils at Site 545.

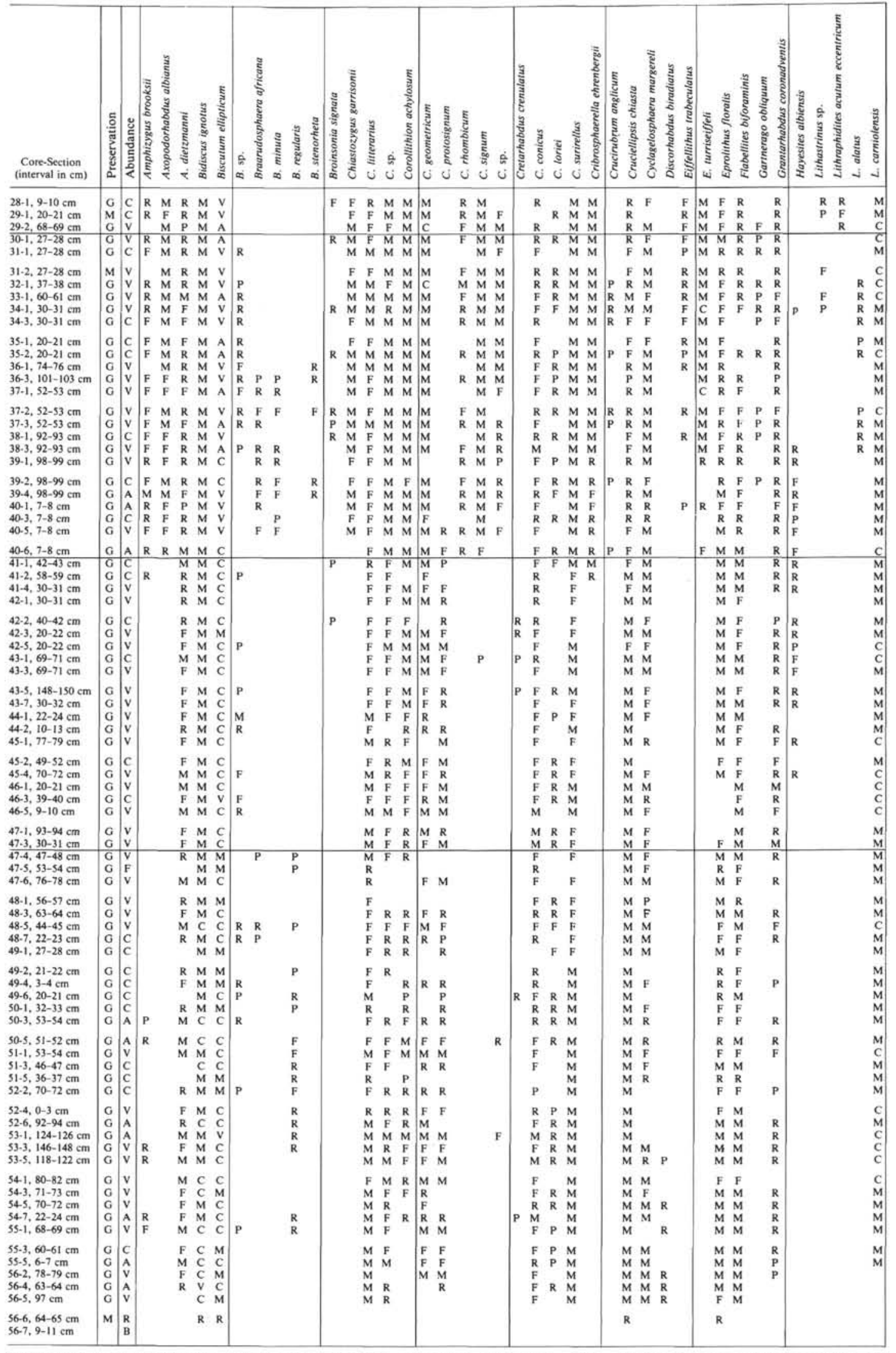

Note: $\mathrm{D}=$ very abundant; $\mathrm{A}=$ abundant; $\mathrm{V}=$ very common; $\mathrm{C}=$ common; $\mathrm{M}=$ moderately common; $\mathrm{F}=\mathrm{few} ; \mathrm{R}=$ rare; $\mathrm{P}=$ present; $\mathrm{E}=$ essentially barren; $\mathrm{B}=$ barren. $\mathrm{Quantitative}$ estimates for these symbols are given in the text. For preservation, $\mathrm{G}=$ good; $\mathrm{M}=$ moderate; $\mathrm{P}=\mathrm{poor}$, as defined in the text. 
Table 2. (Continued).

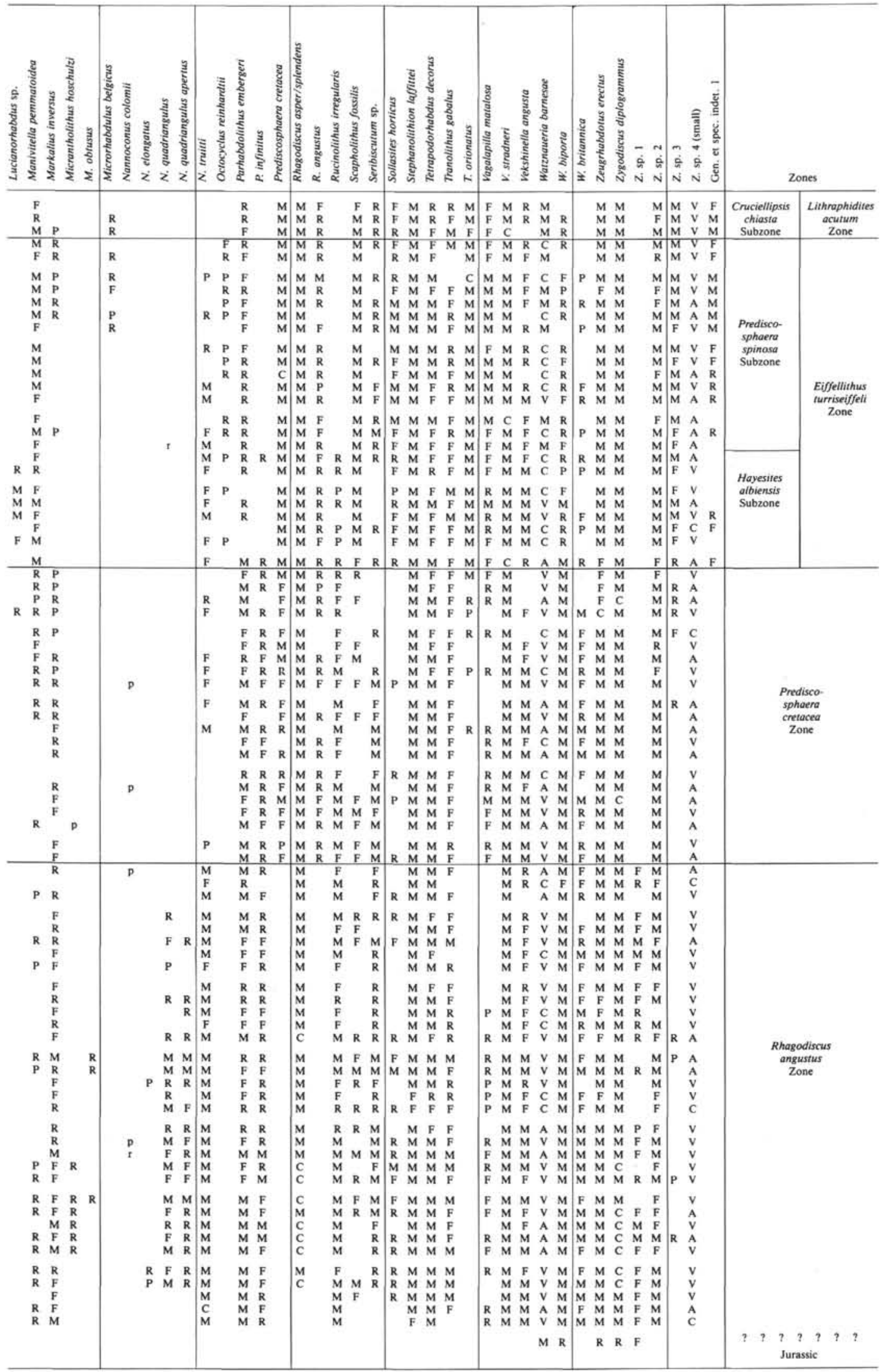


Table 3. Distribution of Cretaceous nannofossils in Holes 547A and 547B.

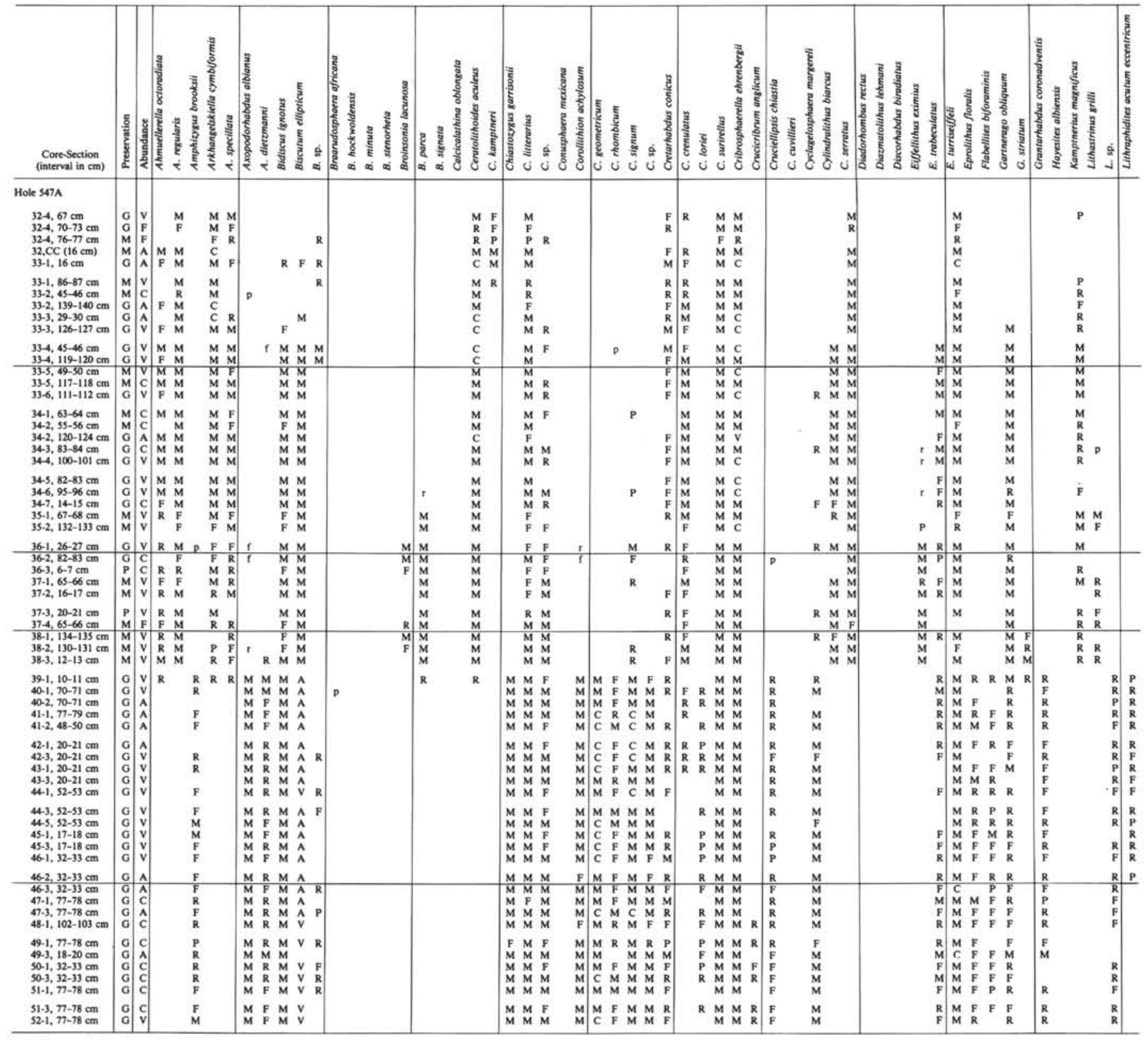

Note: $\mathrm{D}=$ very abundant; $\mathbf{A}=$ abundant; $\mathrm{V}=$ very common; $\mathrm{C}$
$=\mathrm{good} ; \mathrm{M}=$ moderate; $\mathrm{P}=$ poor, as defined in the teat

\section{DISCUSSION}

Legs 14, 41, and 50 of the Deep Sea Drilling Project recovered Cretaceous sediments in the vicinity of Leg 79 (Fig. 1). The sites drilled were Site 135 (Leg 14); Site 370 (Leg 41); and Sites 415 and 416 (Leg 50). Figure 3 shows the correlations among these holes and the Leg 79 holes. Any differences among datums or in the ranges of zones that the correlation is based upon are noted in the discussion that follows.

Site 135 , drilled on a topographic high, recovered poor Upper Cretaceous assemblages, which were assigned a late Campanian-early Maestrichtian age (Tetralithus gothicus trifidus Zone) by Roth and Thierstein (1972). This zone corresponds to the Quadrum trifidum Zone used herein. Lower Albian sediments that correlate to the Chiastozygus litterarius Zone were also recovered.

Site $\mathbf{3 7 0}$ was drilled in a deep basin off Morocco. The Cretaceous interval at this site, lower Valanginian to upper Albian (Čepek, 1978), is somewhat sporadically dated, since unconformities and unzoned intervals are present. Cepek used a Lower Cretaceous zonation similar to that of Thierstein (1973).

Site 415 (Hole 415A) is located in the Agadir Submarine Canyon, south of Sites 370 and 416 . Cepek et al. (1980) assign these Cretaceous sediments to the Lithraphidites alatus and/or Eiffellithus turriseiffeli zones of Cenomanian to late Albian age but question the presence of the $L$. alatus Zone within the interval because only a few $L$. alatus occurred in one sample. The inter- 
Table 3. (Continued).

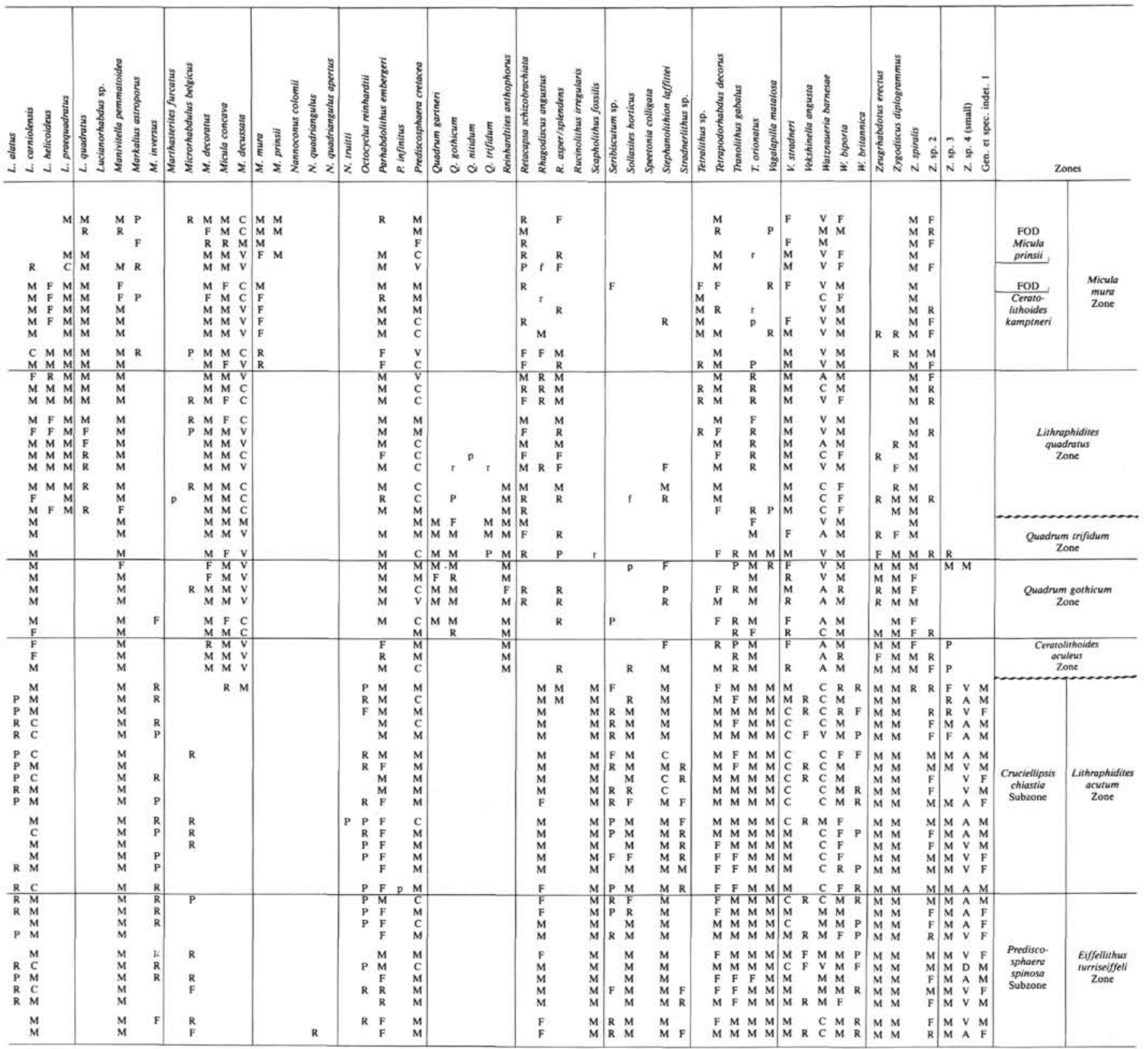

val from the $L$. alatus to the $E$. turriseiffeli zones corresponds approximately to the L. acutum and E. turriseiffeli zones of Manivit et al. (1977).

Hole 416A was drilled in the Morocco Basin very near Site 370. The hole has a limited Albian-lower Aptian section (Cepek et al., 1980) with several barren samples between the short mid-Albian and lower Aptian intervals. The zones used for this short interval are those of Thierstein (1973). The upper Hauterivian-lower Valanginian section is greatly expanded because it is within a turbidite sequence. Cepek et al. (1980) place this section in the Cretarhabdus crenulatus to $L$. bollii zone (Thierstein, 1973).

Site 135 , the most northern site, contains a poor nannofossil assemblage of Campanian-Maestrichtian age. In comparison, the lower Campanian to Maestrichtian of Hole 547A has a larger sediment sequence with a higher diversity of nannofossil species and better defined zones.

The mid-Cretaceous, including the Cenomanian to Aptian, is represented at all the sites. Some sites, such as 415 (Hole 415A) and 135, have few nannofossil zones represented within a considerable sedimentary sequence, whereas others appear to have a continuous record of nannofossil stratigraphic events, as at Sites 545 and 547 (Holes 547A and 547B).

Only Site 370 contains coccoliths of Barremian age. The sediments of this site range from early Valanginian to late Albian in age, with some apparent unconformities and unzoned intervals present. The nannofossil assemblages of Hole 416A are late Hauterivian to early Valanginian in age, and were deposited within a large 
Table 3. (Continued).

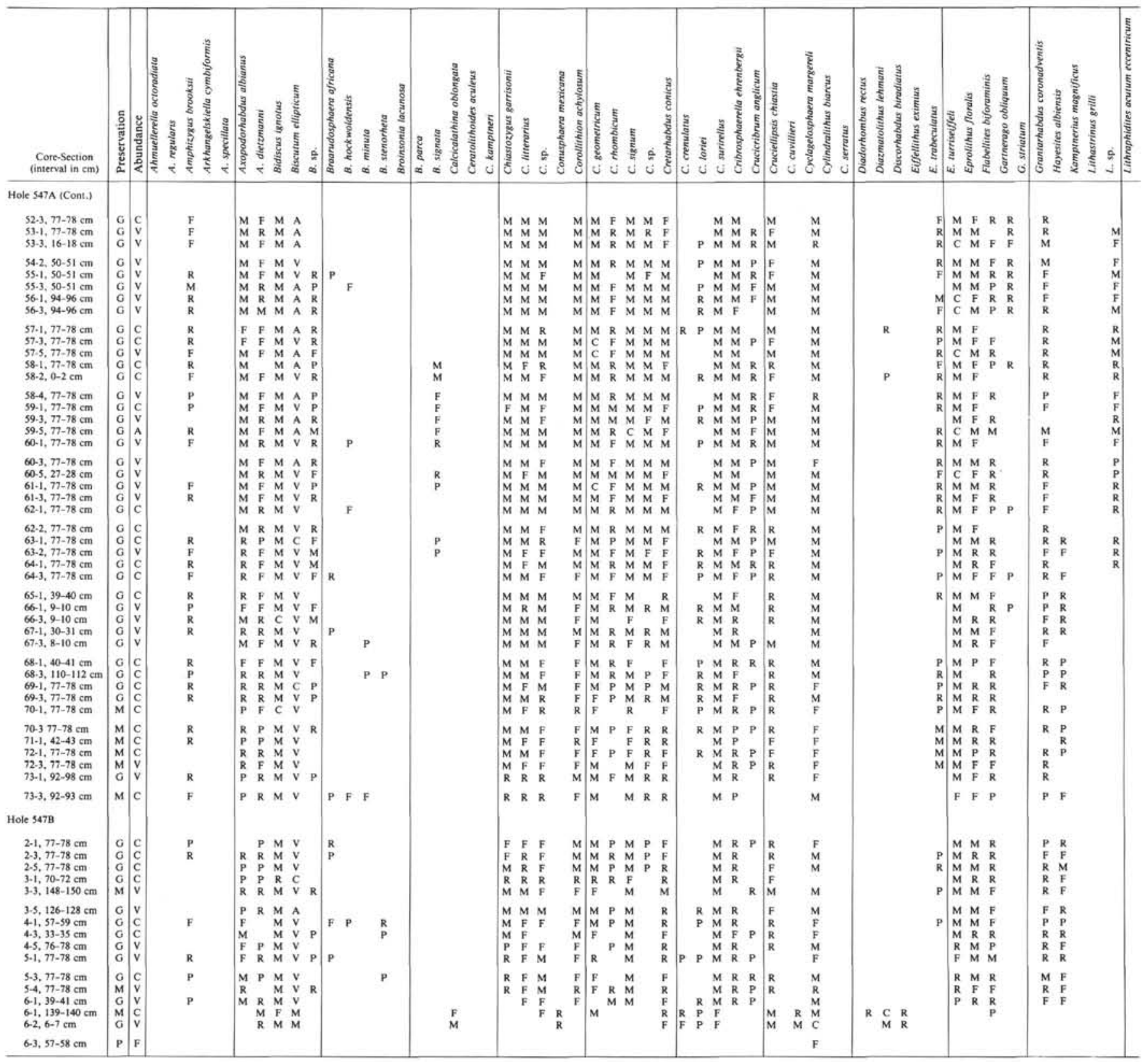

turbidite sequence. Sediments at Sites 370 and 416 were deposited in a basinal setting (Morocco Basin), as evidenced by the turbidites of Hole 416A and the relatively thickened sediment sequence, compared to Hole 547B, of Site 370. Hole 547B contains a limited sequence of lower Valanginian-lower Hauterivian sediment interbedded with limestone that was apparently deposited on the carbonate platform to the north of the other two sites.

All the sites studied have a major unconformity between the Albian or Cenomanian and the Upper Cretaceous (Sites 135 and 547) or the Tertiary (Sites 370, 415, 416, and 545). It appears that the sites (370 and 416) within the Moroccan Basin have unconformities separating the Tertiary from the middle or upper Albian. However, to the north, where sediments were not deposited at such great depths, the youngest sediments below the unconformity at Sites 545 and 547 are middle-upper Cenomanian. The major event (or events) that caused this widespread unconformity does not appear to have affected Sites 135 and 547 so severely as the others, since both have uppermost Cretaceous sediments present.

\section{SUMMARY AND CONCLUSIONS}

The Cretaceous sediments recovered on Leg 79 are predominantly middle and Upper Cretaceous in age, with a minimal amount of lower Valanginian-lower Hauterivian age sediments present. Only a small portion of the Cretaceous sediments has no recoverable record of nannofossils; this is in the lower Valanginian-lower Hauterivian of Hole 547B where limestones are present. However, claystones interbedded with the limestones do have nannofossils. The calcareous nannofossil assemblages for 
Table 3. (Continued).

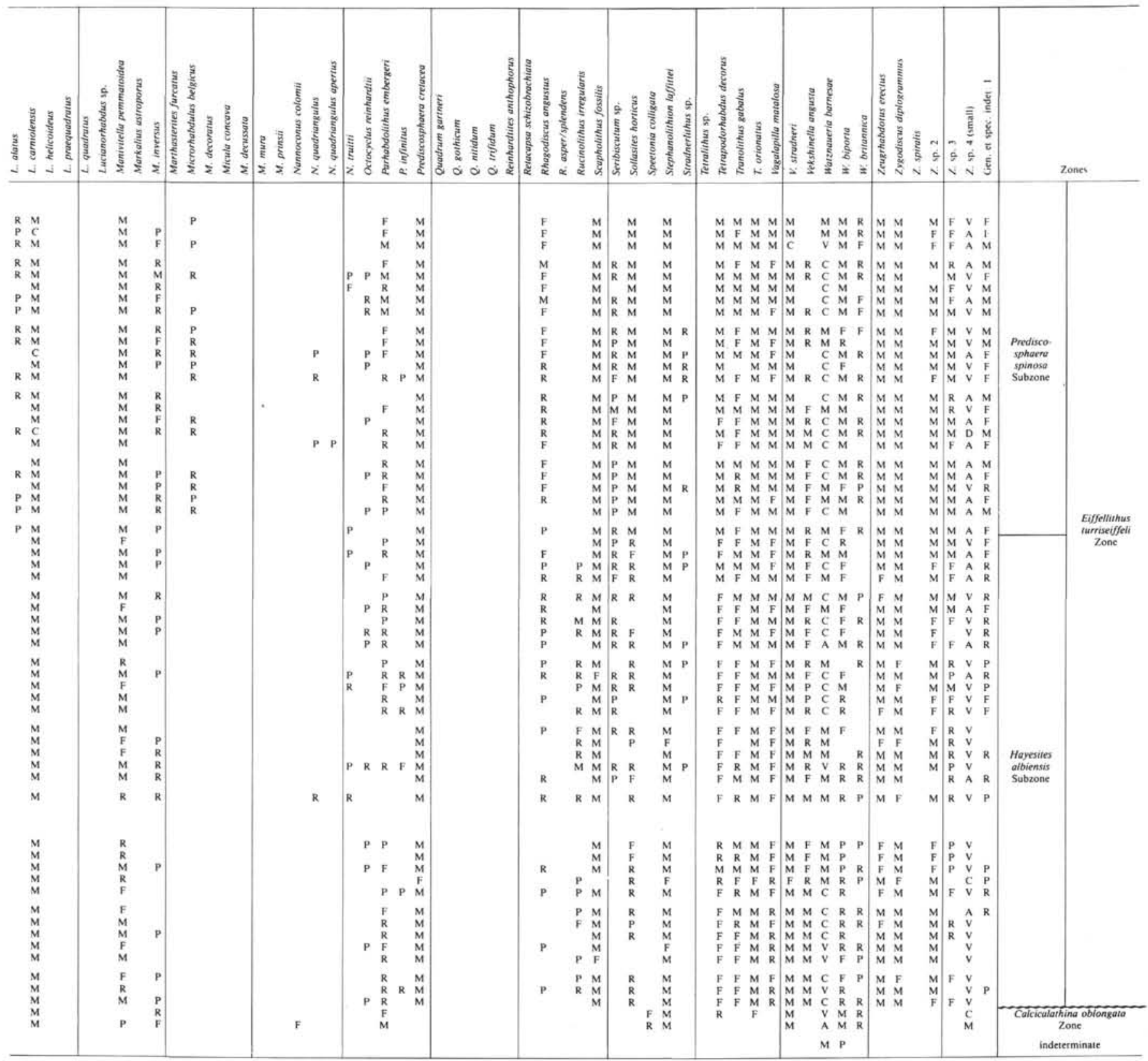

the remainder of the Cretaceous interval typically have high species diversity and good preservation.

The upper Aptian-lower Albian to middle-upper Cenomanian and the middle to upper Maestrichtian intervals provide complete records of recognized nannofossil biostratigraphic events. These two intervals, however, are separated by mid-Campanian-lower Maestrichtian sediments.

The Cretaceous erosional event history of the Mazagan Escarpment is not well reflected in the nannofossil biostratigraphy of Site 545 . Unconformities between the Miocene and the middle-upper Cenomanian, and the upper Aptian-lower Albian and the Middle-Late Jurassic indicate major erosional events along the base of the escarpment. At Site 547, however, hiatuses separate the middle-upper Cenomanian from the lower-middle Campanian and the upper Campanian-lower Maestrichtian from the mid-Maestrichtian. These Cretaceous unconformities found at Sites 545 and 547 do not correspond in age to those found in the Moroccan Basin on Leg 50; thus bracketing the age of the unconformities within the Moroccan Basin is not possible.

A disconformity is found at Site 545 between the dolomitized limestone and overlying dolomitized nannofossil chalk. The nannofossil chalk indicates a more oceanic, deeper water environment than that represented by the platform limestone. Thus the youngest possible age for the drowning event of this portion of the platform is late Aptian-early Albian. The history of the drowning event at Site 547 is not well evidenced by nannofossil 


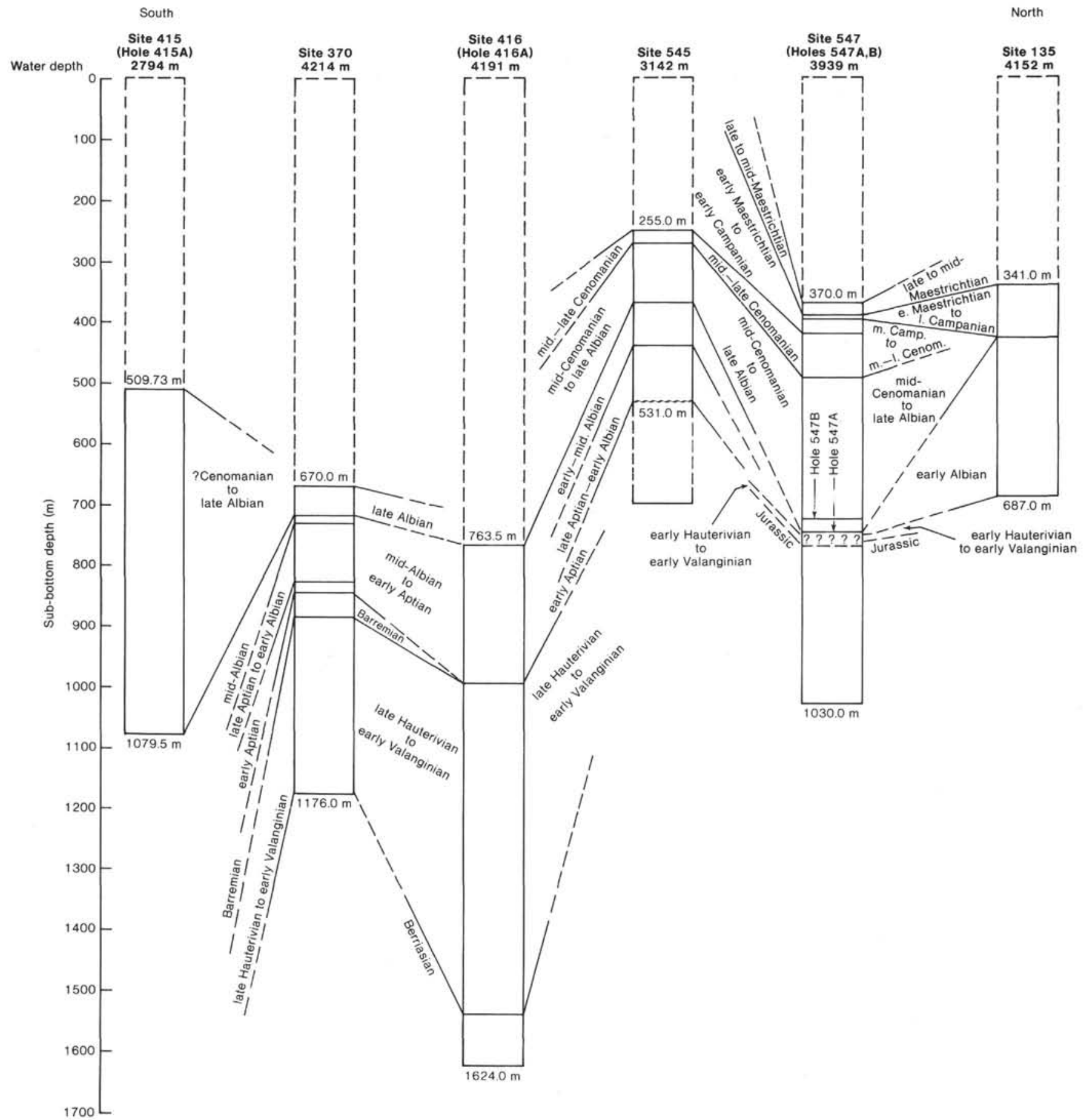

Figure 3. Comparison of Cretaceous stages using nannofossil assemblages from sites of DSDP Legs 14, 41, 50, and 79.

biostratigraphy. The hiatus between the lower Valanginian-lower Hauterivian and upper Albian in Section 547B-6-1 obscures the record, since a large amount of time is absent. The upper Albian nannofossil claystones overlying the unconformity apparently represent the youngest age of deep water sedimentation. The interbedded sequence beneath the unconformity is interpreted as having been deposited at moderate water depths (see Site 547 site chapter, this volume). It appears that between the early Valanginian-early Hauterivian and the late $\mathrm{Al}$ bian, the platform subsided to depths where pelagic sedimentation could occur.

\section{ACKNOWLEDGMENTS}

The author wishes sincerely to thank David K. Watkins, Dr. S. W. Wise, Jr., and James A. Bergen for their helpful comments and discussions, and David Watkins, S. W. Wise, and Hans Thierstein for their critical review of the manuscript. I thank Mary E. Parker and F. Amrisar Kaharoeddin for help in the preparation of the text, Stephen Knüttel for assistance with photography, and Jill Arnold for typing the manuscript. Laboratory support for this study was provided by NSF grants DPP 80-20382 and EAR 80-25489.

\section{REFERENCES}

Bukry, D., and Bramlette, M. N., 1970. Coccolith age determinations Leg 3, Deep Sea Drilling Project. In Maxwell, A. E., von Herzen, 
R. P., et al., Init. Repts. DSDP, 3: Washington (U.S. Govt. Printing Office) 589-612.

Cepek, P., 1978. Mesozoic calcareous nannoplankton of the eastern North Atlantic, Leg 41. In Seibold, E., Lancelot, Y., et al., Init. Repts. DSDP, 41: Washington (U.S. Govt. Printing Office), 667-687.

Čepek, P., Gartner, S., and Cool, T., 1980. Mesozoic calcareous nannofossils, Deep Sea Drilling Project Sites 415 and 416, Moroccan Basin. In Lancelot, Y., Winterer, E. L., et al., Init. Repts. DSDP, 50: Washington (U.S. Govt. Printing Office), 345-351.

van Heck, S. W., 1979a. Bibliography and taxa of calcareous nannoplankton. Internat. Nannoplankton Assoc. Newsletter, 1:AB1-5, A1-12, B1-27.

1979b. Bibliography and taxa of calcareous nannoplankton. Internat. Nannoplankton Assoc. Newsletter, 1:ABVI, A13-28, B28-42.

1980a. Bibliography and taxa of calcareous nannoplankton. Internat. Nannoplankton Assoc. Newsletter, 2:5-34. $1980 \mathrm{~b}$. Bibliography and taxa of calcareous nannoplankton. Internat. Nannoplankton Assoc. Newsletter, 2:43-81. 1981a. Bibliography and taxa of calcareous nannoplankton. Internat. Nannoplankton Assoc. Newsletter, 3:4-41. 1981b. Bibliography and taxa of calcareous nannoplankton. Internat. Nannoplankton Assoc. Newsletter, 3:51-86.

1982a. Bibliography and taxa of calcareous nannoplankton. Internat. Nannoplankton Assoc. Newsletter, 4:7-50.

1982b. Bibliography and taxa of calcareous nannoplankton. Internat. Nannoplankton Assoc. Newsletter, 4:65-96.

1983. Bibliography and taxa of calcareous nannoplankton. Internat. Nannoplankton Assoc. Newsletter, 5:4-13.

Loeblich, A. R., Jr,. and Tappan, H., 1966. Annotated index and bibliography of the calcareous nannoplankton. Phycologia, 5:81-215.

, 1968. Annotated index and bibliography of the calcareous nannoplankton II. J. Paleontol., 42:584-598.

1969. Annotated index and bibliography of the calcareous nannoplankton III. J. Paleontol., 43:568-588.

1970a. Annotated index and bibliography of the calcareous nannoplankton IV. J. Paleontol., 44:558-574.

, 1970b. Annotated index and bibliography of the calcareous nannoplankton V. J. Phycologia., 9:157-174.

, 1971. Annotated index and bibliography of the calcareous nannoplankton VI. J. Phycologia., 10:315-339.

, 1973. Annotated index and bibliography of the calcareous nannoplankton VII. J. Paleontol., 47:715-759.

Manivit, H., 1971. Nannofossiles calcaires du Crétacé français (Aptien-Maestrichtian): Essai de biozonation appuyee sur les stratotypes [These Doct. d'Etat]. Paris: Fac. Sci. d'Orsay.
Manivit, H., Perch-Nielsen, K., Prins, B., and Verbeek, J. W., 1977. Mid-Cretaceous calcareous nannofossil biostratigraphy. $K$. Nederl. Akad. Wet. B, 80:169-181.

Martini, E., 1976. Cretaceous to Recent calcareous nannoplankton from the Central Pacific Ocean (DSDP Leg 33). In Schlanger, S. O., Jackson, E. D., et al., Init. Repts. DSDP, 33: Washington (U.S. Govt. Printing Office), 383-423.

Perch-Nielsen, K., 1979. Calcareous nannofossils from the Cretaceous between the North Sea and the Mediterranean. Aspekte der Kriede Europas: IUGS Series A (Stuttgart), 6:223-272.

Romein, A. J. T., 1977. Calcareous nannofossils from the Cretaceous/Tertiary boundary interval in the Barranco del Gredero (Caravaca, Prov. Murcia, S. E., Spain) I. K. Nederl. Akad. Wet. B, $80: 256-279$.

Roth, P. H., 1978. Cretaceous nannoplankton biostratigraphy and oceanography of the northwestern Atlantic Ocean. In Benson, W. E., Sheridan, R. E., et al., Init. Repts. DSDP, 44: Washington (U.S. Govt. Printing Office), 731-759.

Roth, P. H., and Thierstein, H. R., 1972. Calcareous nannoplankton: Leg 14 of the DSDP. In Hayes, D. E., Pimm, A. C., et al., Init. Repts. DSDP, 14: Washington (U.S. Govt. Printing Office), 421-485.

Sissingh, W., 1977. Biostratigraphy of Cretaceous calcareous nannoplankton. Geol. Mijnbouw, 56:37-65.

Thierstein, H. R., 1971. Tentative Lower Cretaceous calcareous nannoplankton zonation. Eclogae Geol. Helv., 64:459-488. 1973. Lower Cretaceous calcareous nannoplankton biostratigraphy. Abh. Geol. Bundesanst. (Austria), 29:1-52.

,1976. Mesozoic calcareous nannoplankton biostratigraphy of marine sediments. Mar. Micropaleontol., 1:325-362.

Verbeek, J. W., 1977. Calcareous nannoplankton biostratigraphy of Middle and Upper Cretaceous deposits in Tunisia, Southern Spain and France. Utrecht Micropaleontol. Bull., 16:1-157.

Watkins, D. K., and Bowdler, J. L., in press. Cretaceous calcareous nannofossils from Deep Sea Drilling Project Leg 77, southeast Gulf of Mexico. In Buffler, R. T., Schlager, W., et al., Init. Repts. $D S D P, 77$ : Washington (U.S. Govt. Printing Office).

Wind, F. H., and Čepek, P., 1979. Lower Cretaceous calcareous nannoplankton from DSDP Hole 397A (northwest African margin). In von Rad, U., Ryan, W. B. F., et al., Init. Repts. DSDP, 47, Pt. 1: Washington (U.S. Govt. Printing Office), 221-255.

Date of Initial Receipt: November 9, 1983 Date of Acceptance: January 24, 1984 


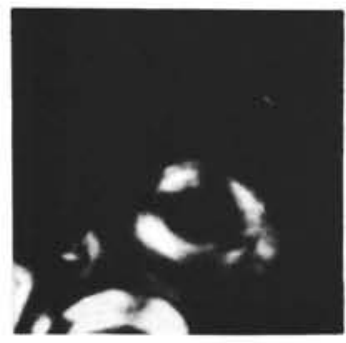

1

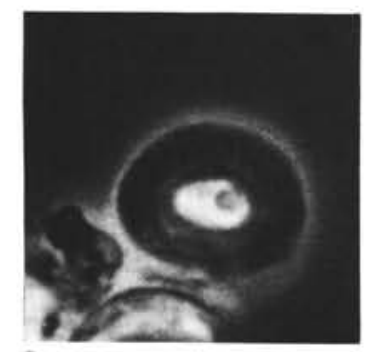

2

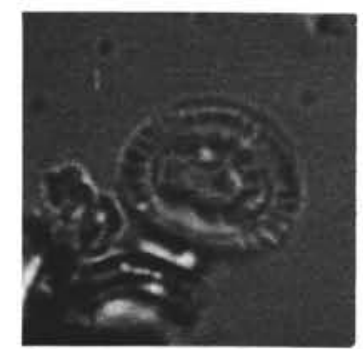

3

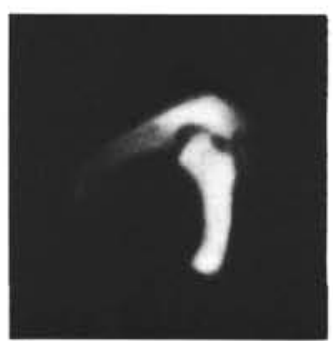

5

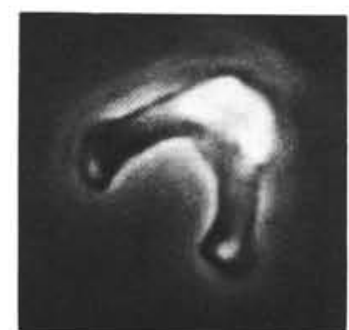

6

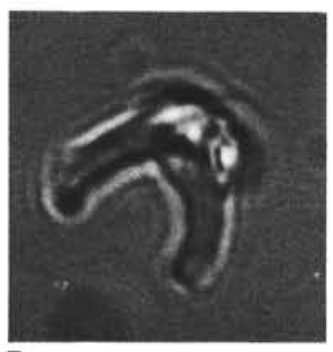

7

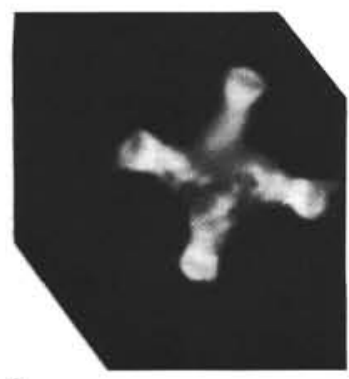

8

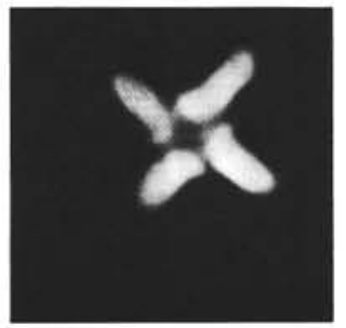

9

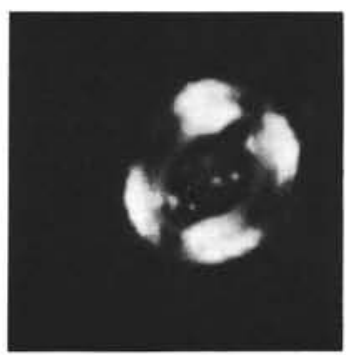

10

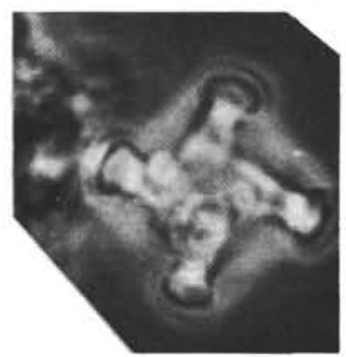

11

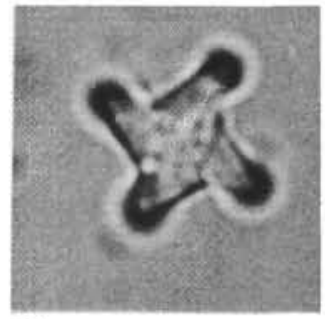

12

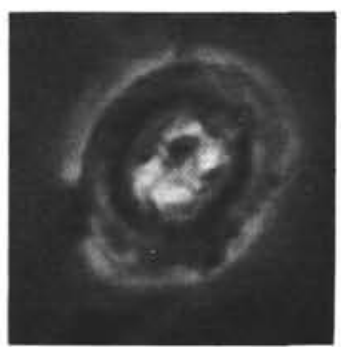

13

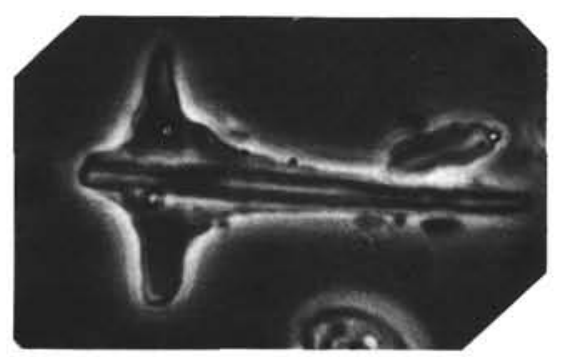

4

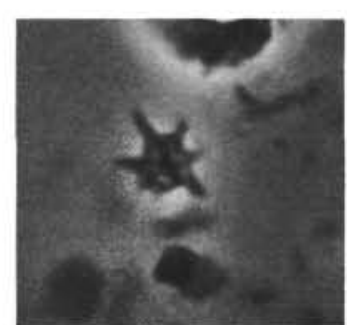

14

Plate 1. Light micrographs of Maestrichtian to Aptian nannofossils. (The abbreviations Pol, $\mathrm{Ph}$ and $\mathrm{Tr}$ denote cross-polarized, phase contrast, and transmitted light.) 1-3. Genus et species indet., $\times 2450$ (1, Pol; 2, Ph; 3, Tr), upper Aptian-lower Albian Sample 545-50-5, 51-52 cm. 4. Lithraphidites acutum ssp. eccentricum, $\times 2250 \mathrm{Ph}$, Cenomanian Sample 547A-42-3, 20-21 cm. 5-7. Ceratolithoides kamptneri, $\times 3350(5$, Pol; 6 , $\mathrm{Ph} ; 7, \mathrm{Tr})$, upper Maestrichtian Sample 547A-32-4, 70-73 cm. 8, 11. Micula prinsii, $\times 3250$ (8, Pol; 11, Ph), upper Maestrichtian Sample 547A-32-4, 70-73 cm. 9, 12. Micula mura, $\times 3300$ (9, Pol; 12, Tr), upper Maestrichtian Sample 547A-32-4, 70-73 cm. 10, 13. Cruciellipsis chiastia, $\times 2350(10$, Pol; 13, Ph), upper Aptian-lower Albian Sample 545-50-5, 51-52 cm. 14. Haysites albiensis, $\times 3200 \mathrm{Ph}$, upper Albian Sample 547B-2-5, $77-78 \mathrm{~cm}$. 